\title{
HUBUNGAN KEHARMONISAN KELUARGA DENGAN DISIPLIN PESERTA DIDIK TAMAN PENDIDIKAN AL-QURAN BAITUL HASANAH KECAMATAN SUMPUR KUDUS KABUPATEN SIJUNJUNG
}

\author{
Eby Anggraini \\ Program Studi Pendidikan Luar Sekolah \\ FIP Universitas Negeri Padang \\ Email : eby.anggraini@ymail.com
}

\begin{abstract}
This research is conducted based on the low condition of the student's discipline in Al-Qur'an Education Center Baitul Hasanah. It is presumed because of less the student to the family harmonism. This research is aimed to observe how is the image of perception to family harmonism, condition of the students' discipline in AlQur'an Education Center Baitul Hasanah, and also to see the relationship between to the family harmonism and the student's discipline in the Al-Qur'an Education Center Baitul Hasanah. This research is co relational- quantiative research which the subject of this research is taken from the student of Al-Qur'an Education Center Baitul Hasanah. The number of the subject is 20 students. The result of the research is showed that there is a significant relationship between the family harmonism and student's discipline in Al-Qur'an Education Center Baitul Hasanah.
\end{abstract}

Keywords: family harmonism, and discipline

\section{PENDAHULUAN}

Menurut UU No. 20 Tahun 2003 tentang Sisdiknas, penyelenggaraan pendidikan dapat diselenggarakan melalui jalur pendidikan sekolah atau yang di sebut dengan pendidikan formal dan jalur pendidikan luar sekolah yang di kenal dengan pendidikan nonformal dan pendidikan Informal. Jalur pendidikan formal diselenggarakan di sekolah dan jalur pendidikan nonformal diselenggarkan di lingkungan masyarakat sedangkan jalur pendidikan informal diselenggarkan di lingkungan keluarga. Jalur pendidikan nonformal diselenggarakan di lingkungan masyarakat yang terdiri atas berbagai satuan dan jenis program.

Dengan mengacu pada UU No. 20 Tahun 2003 tentang sisdiknas, pasal 26 ayat (4), tercantum bahwa 
"Satuan pendidikan nonformal terdiri atas lembaga kursus, lembaga pelatihan, pusat kegiatan belajar masyarakat, majelis taklim, serta satuan pendidikan yang sejenis. Adapun jenis-jenis pendidikan yang sejenis terdiri atas pondok pesantren,TPQ /TQA, mejelis ta'lim, wirid remaja, didikan subuh dan sanggar seni"

TamanPendidikanAl-Quran(TPA) tidak dapat melepaskan diri dan situasi kehidupan masyarakatdan mempunyai tanggung jawab untuk membantu anak sebagai pribadi ataupun sebagai calon anggota masyarakat.Sebagai suatu lembaga pendidikan nonformalTaman Pendidikan Al - Qur'an bertanggung jawab untuk mendidik dan menyiapkan anak agar berhasilmenyesuaikan diri di masyarakat dan mampu memecahkan berbagai masalahyang dihadapi.Kegiatan belajar mengajar merupakan salah satu kegiatan yangdiberikan TPA. Namun sesungguhnya kegiatan itu saja belum cukupmemadai dalam menyiapkan anak untuk terjun ke masyarakat dengan berhasil, maka hendaknya lingkungan TPA dan lingkungan keluarga memberikan bantuan secara pribadi kepada anak agarmampu memecahkan masalah yang dihadapi. Anak hendaknya dibantu agar apayang mereka terima di TPA dapat menjadi bekal untuk menjadikan anak sebagai anggotamasyarakat yang mandiri dan mampu memecahkan masalah yang dihadapi.

Salah satu masalah yang sering dihadapi anak adalah masalah yang berkaitan dengan belajar.Beragamnya persoalan belajar hampir tiap hari dialami anak sehingga anak memerlukan bantuan untuk mengatasi persoalan tersebut. Satu hal lain yang berhubungan dengan masalah belajar adalah disiplin anak. Seorang peserta didik TPA yang berdisiplin dalam belajar tentu akan mudah dalam mengikuti proses pembelajaran di TPA, demikian juga sebaliknya.

Keluarga merupakan salah satu faktor penting dalam menentukan keberhasilan anak. Keluarga merupakan tempat pendidikan pertama dan utama bagi setiap anak, juga bertindak sebagai pendidik dan pembimbing. Peran ibu dan ayah sangat penting untuk mewarnai keberhasilan belajar guna untuk mencapai tujuan nasional. 
Orang tua sangat berperan untuk mewujudkan keberhasilan pendidikan, mencerdaskan anak- anak, guna mengembangkan segala potensi yang masih terpendam dalam diri anak.

Faktor-faktor yang dapat mempengaruhi belajar anak salah satunya adalah keluarga. Orang tua yang memperhatikan anaknya, seperti orang yang acuh tak acuh terhadap belajar anak, tidak memperhatikan sama sekali akan kepentingan- kepentingan dan kebutuhankebutuhan anak dalam belajar, tidak mengatur waktu belajar anak, tidak memperhatikan anak belajar, tidak tahu bagaimana kemampuan anaknya belajar, tidak mau tahu bagaimana kemajuan belajar anaknya, kesulitan-kesulitan yang dialami anak dalam belajar dan terpenting kurang adanya keharmonisan dalam keluarga sehingga membuat anak tidak nyaman berada di tengah- tengah keluarga tersebut. Hal ini memberikan pengaruh yang sangat besar pada perkembangan diri anak, terlebih dalam disiplin anak di TPA.

Menurut Bahri (2004) keluarga adalah sebuah insitusi pendidikan yang utama dan bersifat kodrati. Sebagai komunitas masyarakat yang luas. Oleh karena itu, kehidupan keluarga yang harmonis perlu dibangun diatas dasar sistem interaksi yang kondusif sehingga pendidikan dapat berlansung dengan baik.

Keharmonisan adalah hal yang sangat penting dan menjadi dambaan bagi setiap keluarga. Perkembangan belajar dan disiplin peserta didik di TPA sangat dipengaruhi oleh tingkat keharmonisan keluarga tempat ia bernaung. Jika peserta didik tumbuh dari keluarga yang harmonis, maka disiplin dan belajarnyapun baik, ia tidak akan mudah terjerumus kedalam tingakah laku yang salah.

Taman Pendidikan Al-Quran (TPA) Baitul Hasanah terletak di Jorong Pincuran Tujuh Kanagarian Tanjung Bonai Aur Selatan. Pendidik TPA Baitul Hasanah yaitu sebanyak 2 orang.Kegiatan pembelajaran TPA Baitul Hasanah berlansung pada hari Rabu sampai hari Minggu, dan jam pelajarannya untuk kelas I dan II dimulai pada pukul 14.00WIB-15.30WIB, 
sedangkan untuk kelas III dimulai setelah shalat azhar sekitar pukul 16.00WIB-17.00WIB. Peserta didik di TPA ini yaitu sebanyak 50 orang dengan rincian sebagai berikut:

Tabel 1 Jumlah Peserta Didik

\begin{tabular}{|c|c|c|}
\hline No & Kelas & Peserta Didik \\
\hline 1 & Satu & 15 orang \\
\hline 2 & Dua & 15 orang \\
\hline 3 & Tiga & 20 orang \\
\hline \multicolumn{2}{|c|}{ Jumlah } & 50 orang \\
\hline
\end{tabular}

Sumber: Taman Pendidikan Al-quran Baitul Hasanah

Pada waktu peneliti melakukan observasi di TPA Baitul Hasanah pada tanggal 25 September 2013, penulis melihat pendidik memulai jam pelajaran 14.00 WIB untuk kelas I dan II. Saat jam pelajaran dimulai penulis melihat peserta didik yang mengkuti pelajaran hanya 7 orang kelas I dan 5 orang kelas II. Lima belas menit setelah jam pelajaran berlansung penulis melihat datang peserta didik sebanyak lima orang, 2 orang kelas I dan 3 orang kelas II. Kemudian disusul lagi dengan 2 orang kelas I dan 4 orang kelas II. Selama jam pelajaran berlansung, di kelas I penulis melihat banyak peserta didik yang kurang memperhatikan pelajaran, ada diantara mereka yang asik mengombrol dengan teman disampingnya, ada yang mengganggu teman, ada juga yang asik dengan diri sendiri. Selajudnya di kelas II penulis melihat hal yang sama, mengombrol dengan teman disampingnya, memakan makanan saat pelajaran berlansung, saat ditegur pendidik mereka berenti sebentar setelah itu merela menggulanginya lagi. Setelah pukul 15.30 WIB jam pelajaran berakhir untuk kelas I dan kelas II., disaat pendidik mereka mengatakan jam pelajaran berakhir, mereka bersorak - sorak dan berlari meletakan Al-quran, tetapi penulis melihat mereka meletakan Al-Quran sesuaka hati mereka sehingga Al-Quran tidak tersusun rapi. Saar jam pelajaran berakhir penulis melihat banyak peserta didik yang lansung pulang kerumah mereka dan ada juga yang menunggu waktu azar untuk shalat berjamaah. Selanjudnya setelah shalat azar berjamaah kelas III memulai pelajaran, disana penulis melihat peserta didik yang datang hanya 10orang, dana ada yang terlambat 6 orang. Dalam proses 
pembelajaran penulis melihat tidak jauh berbeda dari kelas satu dan kelas dua, mereka mengobrol dengan teman mereka, memperolok2 teman saat jam pelajaran.

Setelah jam pelajaran kelas III berakhir penulis melakukan wawancara dengan pendidik TPA Baitul Hasanah yaitu ibu Janiar. Penulis menyakan, bagaimana peserta didik disini buk? ibuk Janiar menjawab "seperti yang saudara liat, mereka banyak yang terlambat, bahkan kadang tidak datang ke TPA, mereka sering mengombrol dengan teman yang duduk disebelah mereka, memperolok-olokan teman, saat saya menegurnya, ada diantara mereka yang melawan". Selanjudnya penulis menyakan apakah diantara mereka selanjudnya penulis menanyakan apakah banyak peserta didik yang melanggar aturan buk? ibu janiar menjawab" banyak diantara mereka yang melanggar aturan, seperti terlambat datang ke TPA, tidak membawa buku catatan, tidak memakai pakaian muslim, tidak mengerjakan tugas, tidak melaksanakan piket”. Kemudian penulis menanyakan apakah tidak ada sangsi yang diberikan buk? kemudia buk janiar menjawab " ada sangsi untuk mereka, ada yang mengertkannya, ada juga yang yang terpaksa mengerjakannya”.

Dari wawancara penulis dengan ibu Janiar diperoleh informasi banyak peserta didik yang terlambat bahkan tidak datang mengikuti pelajaran di TPA, dan banyak peserta didik yang tidak memematuhi peraturan TPA seperti tidak membawa buku catatan, tidak memakai pakaian muslim, tidak mengerjakan tugas individu, tidak mengerjakan perintah yang disuruh oleh guru,tidak mengerjakan piket, tidak mengerkajan sangsi yang diberikan dengan sepenuh hati.

Berdasarkan masalah di atas banyak peserta didik yang kurang disiplin seperti ketepatan waktu, ketaatan pada peraturan dan kurang tanggung jawab, maka penulis tertarik melakukan penelitian apakah ada hubungan keharmonisan keluarga dengan disiplin peserta didik di Taman Pendidikan Al-Quran Baitul Hasanah. 
Tujuan penelitian ini adalah (1) untuk melihat keharmonisan keluarga, (2) untuk melihat disiplin peserta didik Taman Pendidikan Al-Quran Baitul Hasanah, (3) untuk melihat hubungan persepsi tehadap keharmonisan keluarga dengan disiplin peserta didik Taman Pendidikan Al-Quran Baitul Hasanah Jorong Pincuran Tujuh, Kanagarian Tanjung Bonai Aur Selatan, Kecamatan Sumpur Kudus, Kabupaten Sijunjung.

\section{METODOLOGI PENELITIAN}

Penelitian ini merupakan penelitian kuantitatif dengan jenis korelasional. Dalam penelitian ini variabel yang akan diteliti yaitu keharmonisan keluarga sebagai variavel (X) dengan disiplin peserta didik di Taman Pendidikan Al-Quran Baitul Hasanah sebagai variabel $(\mathrm{Y})$.

Populasi yang digunakan dalam penelitian ini adalah peserta didik Taman Pendidikan Al-Qur'an Baitul Hasanah yang berjumlah 39 orang. Teknik pengambilan sampel adalah Claster Random samplingyaitu pengambilan sampel secara berkelompok.Dengan demikian jumlah sampel dalam penelitian ini adalah 50\% dari jumlah populasi maka jumlah sampelnya adalah 20 orang.Teknik pengumpulan data adalah wawancara dan alat pengumpulan data adalah pedoman wawancara terstuktur.

Untuk menggambarkan keharmonisan keluarga dan disiplin peserta didik di Taman Pendidikan Al-Quran digunakan rumus analisis persentase (\%). Selanjudnya untuk melihat hubungan antara variabel (x) dan variabel (y) menggunakan rumus rank order.

\section{HASIL PENELITIAN}

Gambaran Keharmonisan Keluarga Peserrta Didik Taman Pendidikan Al-Quran Baitul Hasanah

Gambaran persepsi peserta didik terhadap keharmonisan keluarga dapat dilihat pada diagram berikut: 


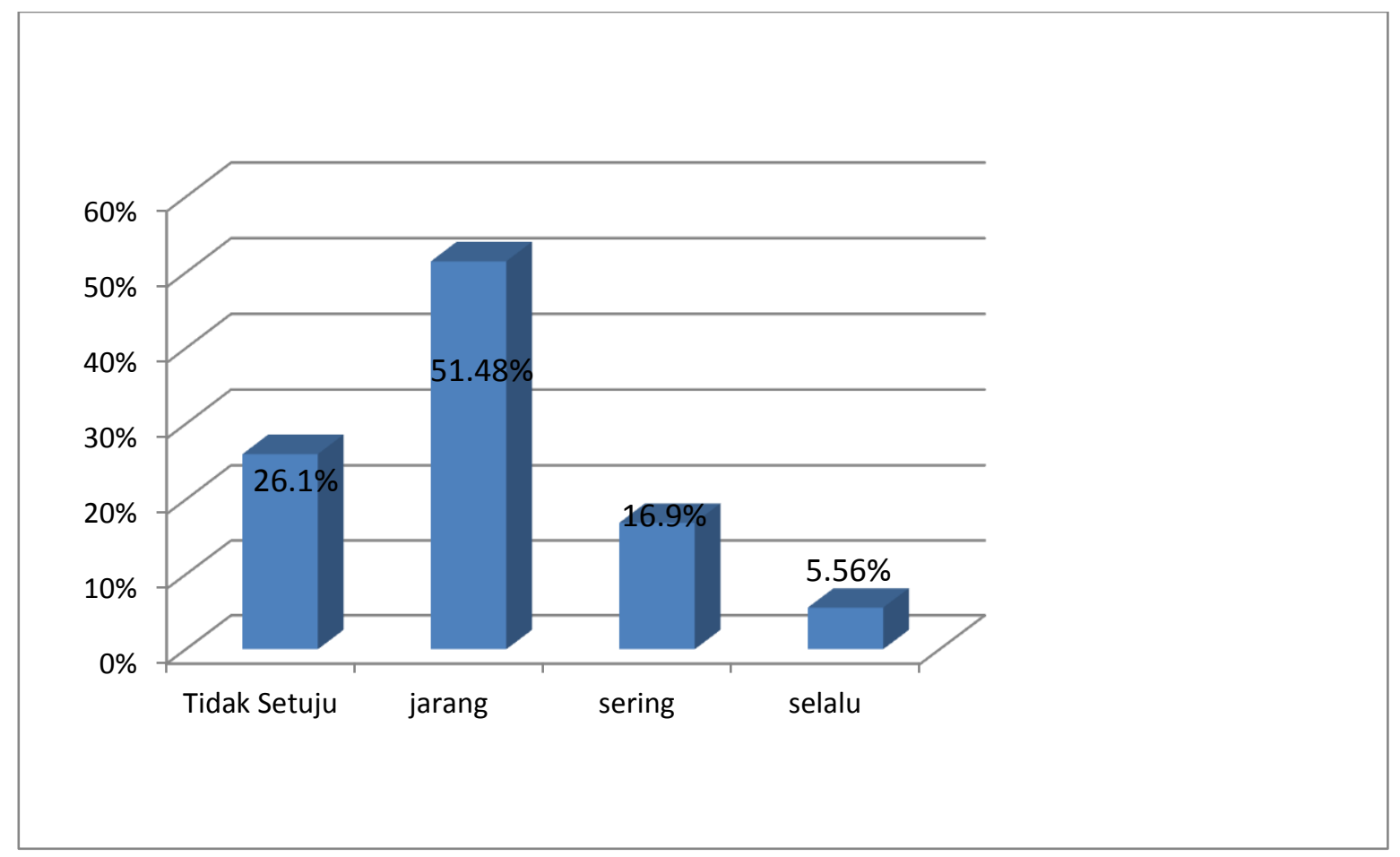

Berdasarkan diagram 1 menggambarkan keharmonisan keluarga peserta didik Taman Pendidikan Al-Quran Baitul Hasanah. Sebanyak 26.1\% responden memberikan pernyataan tidak pernah.51.48\% responden memberikan pernyataan jarang/ JR, sebanyak $16.9 \%$ responden memberikan pernyataan sering/S, dan sebanyak $5.56 \%$ responden memberikan pernyataan selalu/S

Hasil diagram diatas menunjukan keharmonisan keluarga peserta didik Taman Pendidikan Al-Quran Baitul Hasanah kurang harmonis., hal ini terlihat 51,48\% peserta didik menjawab jarang.

\section{Gambaran Disiplin Peserta Didik Taman Pendidikan Al-Quran Baitul Hasanah}

Gambaran disiplin peserta didik di Taman Pendidikan Al-Quran Baitul Hasanah secara keseluruhan dapat dilihat pada diagram berikut: 


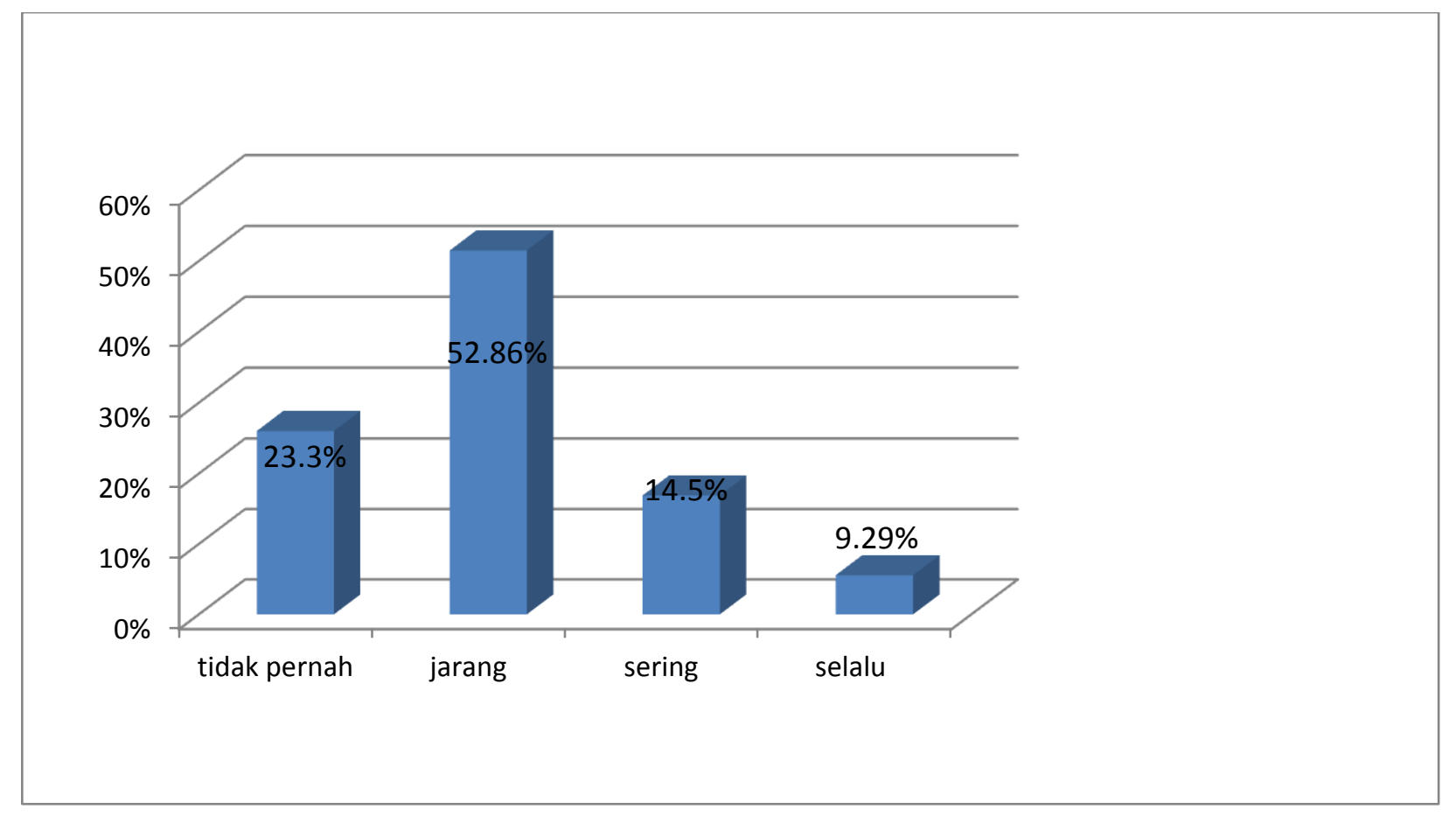

Berdasarkan diagram 2 menggambarkan disiplin peserta didik Taman Pendidikan AlQuran Baitul Hasanah Jorong Pincuran Tujuh Kanagarian Tanjung Bonai Aur Selatan. Sebanyak $23.3 \%$ responden memberikan pernyataan tidak pernah/TP, sebanyak $52.86 \%$ responden memberikan pernyataan Jarang/JR, sebanyak $14.5 \%$ memberikan pernyataan SeringS, dan sebanyak $9.29 \%$ memberikan pernyataan selalu/S.

Hasil histogram diatas menggambarkan bahwa disiplin peserta didik Taman Pendidikan Al-Qur'an Baitul Hasanah rendah, terlihat dari 52,86\% peserta didik menjawab Jarang.

\section{Gambaran Keharmonisan Keluarga dengan Disiplin Peserta Didik di Taman Pendidikan Al-Quran Baitul Hasanah}

Berdasarkan analisis data diatas yang diuji dengan menggunakan rumus rang order didapat $r_{\text {hitung }}=0.761$ dan setelah dikonsultasikan dengan nilai $r_{\text {tabel }}$ untuk $n=20$ dengan taraf standar kesalah 5\% (0,396) maupun tingkat kepercayaan 95\% (0.39). Ternyata dapat dilihat bahwa $\mathrm{r}_{\text {hitung }}>\mathrm{r}_{\text {tabel }}$ baik taraf standar kesalahan $5 \%$ ( 0.396) maupun tingkat kepercayaaan 95\% (0.396). Dengan demikian dapat disimpulkan bahwa terdapat hubungan yang siknifikan 
antara Keharmonisanya dengan Disiplinnya di Taman Pendidikan Al_Quran Baitul Hasanah Jorong Pincuran Tujuh Kanagarian Tanjung Bonai Aur Selatan artinya hipotesis diterima.

Kemudian dilakukan uji signifikan koefisien korelasi antara keharmonisan keluarga dengan disiplin peserta didik Taman Pendidikan Al-Quran Baitul Hasanah, ternyata $t_{\text {hitung }}$ lebih besar dari $\mathrm{t}_{\text {tabel }} 4.6>0.591$ maka $\mathrm{H}_{\mathrm{o}}$ ditolak, $\mathrm{H}_{1}$ diterima artinya ada hubungan yang signifikan antara keharmonisan keluarga dengan disiplin peserta didik di Taman Pendidikan Al-Quran Baitul Hasanah Jorong Pincuran Tujuh Kanagarian Tanjung Bonai Aur Selatan.

\section{PEMBAHASAN}

\section{Gambaran Keharmonisan Keluarga Peserta Didik Taman Pendidikan Al-Quran Baitul Hasanah}

Dari hasil penelitian diatas dapat digambarkan bahwa keharmonisan keluarga peserta didik taman pendidikan al-quran baitul hasanah kurang harmonis . Hal ini menunjukan peserta didik belum mempersepsi keluarga mereka sebagai keluarga yang harmonis. Keharmonisan keluarga dalam penelitian ini dilihat dari menciptakan kehidupan berama, meluangkan waktu bersama dalam keluarga, komunikasi yang baik antar sesama anggota keluarga, saling menghargai antar sesama anggota keluarga, kuantitas dan kualitas konflik yang minim, dan hubungan atau ikatan yang erat antar anggota keluarga.

Ma'shum (2010) menyatakan bahwa kondisi keluarga yang harmonis ditandai dengan suatu bentuk komunikasi yang baik antara bapak dan ibu, orang tua dengan anak dan anak dengan saudaranya. Keluarga yang tidak harmonis akan berpengaruh terhadap perilaku anak. Dimana anak yang berasal dari keluarga tidak harmonis akan berperilaku sesuka hati mereka tanpa ada pengawasan dari orang tua. Hal ini sesuai dengan pendapat Hurlock (1993) yang menyatakan bahwa hubungan keluarga yang buruk akan berpengaruh terhadap perilaku anak, karena anak akan merasa terbebani oleh masalah yang dihadapi keluarga. 
Setiap keluarga harus bisa mencipta kehidupan beragama dalam keluarganya. Hal ini sesuai dengan pendapat Sayekti (dalam Shochib 2010) yang mengatakan nilai-nilai agama sangat besar pengaruhnya terhadap keberhasilan suatu keluarga. Keluarga yang tidak didasari nilai-nilai agama, maka perilaku setiap anggota keluarga tidak akan bisa dikendalikan dengan baik sehingga keharmonisan dalam suatu keluarga tidak akan terwujud. Maka dari itu Hawari (1997) mengatakan keharmonisan keluarga terwujud apabila masing- masing unsur dalam keluarga itu dapat berfungsi dan berperan sebagai mana mestinya dan tetap berpegang teguh pada nila- nilai agama.

Shochib (2010) mengatakan orang tua yang sibuk atau hanya memberikan kebutuhan materi kepada anak membuat anak merasa kurang diperhatikan sehingga rasa kebersamaan dan keterbukaan didalam keluarga tidak dirasakan oleh anak. Jika dalam suatu keluarga tidak terjadi komunikasi yang baik antar sesama anggota keluarganya, maka anak akan merasa tidak bebas mengeluarkan pendapatnya dirumah, dan anak akan mempersepsi keluarga mereka sebagai keluarga yang tidak harmonis. Hal ini sesusai dengan pendapat Madison (dalam Shochib 2010) yang mengatakan komunikasi dalam keluarga sangat dibutuhkan agar anak bisa mengungkapkan perasaan, pikiran dan uneg-unegnya. Keluarga kacau atau keluarga yang sering terjadi konflik dan kurang peka memenuhi kebutuhan anak, anak sering diabaikan dan diperlakukan secara kejam karena kesenjangan hubungan antara mereka dengan orang tua. David (dalam Shochib 2010) Keluarga kacau selalu tidak rukun dan hubungan antara anggota keluarga tidak berjalan dengan baik sehingga anak merasa terancam dan tidak disayangi. Orang tua yang sering bertengkar dan anak yang sering bertengkat dengan saudaranya membuat kondisi rumah tidak menyenangkan. Orang tua yang sering memarahi anak akan membuat anak melawan kepada orang dan anak akan mempersepsi ruamah mereka bukanlah tempat yang menyenangkan. 
Dari pendapat diatas dapat ditarik kesimpulan yang menyebabkan kurangnya keharmonisan dalam suatu keluarga adalah kurangnya penanaman nilai-nilai agama dalam keluarga, kesibukan orang tua yang tidak bisa meluangkan waktunya untuk berkumpul dengan anggota keluarga, tidak tewujudnya saling menghargai antar sesama anggota keluarga, dak konflik keluarga yang membuat anak tidak nyaman berada dalam keluarga, serta hubungan atau ikatan yang erat antar anggota keluarga tidak terjalin dengan baik, sehingga anak merasa kurang mendapatkan kasih sayang kepada orang tua. Untuk itu perlunya keharmonisan dalam suatu keluarga agar anak bisa mempersepsi keluarga mereka sebagai keluarga yang harmonis dan anak akan merasa nyaman dan merasakan kasih sayang dari anggota keluarga sehingga perilakulaku anak sesuai dengan norma-norma yang berlaku.

\section{Deskripsi Disiplin Peserta Didik di Taman Pendidikan Al-Quran Baitul Hasanah}

Berdasarkan temuan penelitian terhadap disiplin peserta didik yang dilihat dari ketepatan waktu, ketaatan dan tanggung jawab di TPA Baitul Hasanah maka diperoleh hasil bahwa disiplin peserta didik di TPA Baitul Hasanah rendah. Dari hasil penelitian diatas terlihat disiplin peserta didik sangat dipengaruhi oleh keharmonisan suatu keluarga. Dengan keluarga yang harmonis anak akan mempunyai disiplin yang tinggi di TPA. Hal ini sesuai dengan pendapat Shochib (1997) yang mengatakan rendahnya disiplin anak dilatar belakangi oleh situasi dan kondisi keluarga yang negatif atau tidak harmonis.

Satrohadiwityo (2002) mengemukakan bahwa disiplin sebagai suatu sikap seseorang dalam menghargai waktu kesadaran dan kepatuhan terhadap peraturan yang berlaku, baik yang tertulis maupun yang tidak tertulis, serta sanggup menjalankannya dan tidak mengelak sangsi-sangsinya apabila ia mendengar tugas dan wewenang yang diberikan padanya.

Dalam proses pembelajaran di TPA disiplin merupakan masalah yang patut diperhatikan, sebab adanya kedisiplinan bukan hanya sekedar menunjukan indikasi turunya 
semangat dan kegairahan belajar tetapi dapat mempengaruhi pencapaian tujuan belajar. Kedisiplinan merupakan salah satu sarana dan kunci untuk mencapai kesuksesan dan keberhasilan, untuk itu perlu ditimpal kesadaran dari individu tentang perlunya kedisiplinan diri terhadap segala sesuatu yang dilakukan.

Seorang yang ditepat waktu adalah orang yang selalu tetap waktu datang ke TPA, dan mengerjakan tugas yang diberikan sebagaimana dikatakan Anora (2001) seorang yang berdisiplin tinggi adalah orang tepat waktu dalam melaksanakan tugas dan tanggung jawab dan selalu mematuhi aturan dan tatatertib yang berlaku. Artinya seorang peserta didik yang tidak tepat waktu datang ke TPA dan selalu terlambat mengumpulkan tugas yang diberikan, serta tidak mempunyai tanggung wajab atas tugas yang diberikan dirinya dan selalu melanggar peraturan yang berlaku, bukanlah peserta didik yang yang mempunyai disiplin. Hal senada dikemukakan oleh Nitisesmito (1982) bahwa adanya keterlambatan dalam melaksanakan tugas dan tanggung jawab diluar kebiasaan dan dapat menunjang indikasi disiplin seseorang rendah yang disebabkan oleh karena kemalasan. Jika kemalasan seseorang berlarut-larut akan mengakibatkan disiplin seseorang tersebut menurun. Artinya orang yang sering terlambat datang ke TPA, tidak mengerjakan tugas dan tidak melaksanakan piket disebabkan oleh kemalasan, dan kemalasan terus menus akan membuat peserta didik tidak disiplin. Selanjudnya Poerwadarminta (2003) mengatakan disiplin adalah suatu ketaatan dan kepatuhan pada aturan dan tata tertib.Maksudnya adalah peserta didik yang disiplin adalah peserta didik yang selalu mematuhi aturan dan pertintah yang diberikan pendidik bukan peserta didik yang selalu melanggar aturan dan melawan kepada pendidiknya.

Dari uraian diatas dapat disimpulkan peserta didik tidak memiliki disiplin di TPA adalah peserta didik yang berasal dari keluarga yang kurang harmonis. Maka dari itu untuk menunjang disiplin peserta didik harus di dukung oleh keluarga yang harmonis, dimana keluarga yang harmonis terciptanya komunikasi yang baik untuk mengatasi masalah - 
masalah yang dihadapi anak di TPA sehingga proses belajar mengajar di TPA dapat terlansana dengan baik dan tujuan pembelajaranpun dapai dicapai.

\section{Hubungan Keharmonisan Keluarga dengan Disiplin Peserta Didik Taman Pendidikan Al-Quran Baitul Hasanah}

Berdasarkan hasil analsis data yang diperoleh bahwa hipotesis yang diajukan "terdapat hubungan yang sangat siknifikan antara keharmonisan keluarga dengan disiplin peserta didik di Taman Pendidikan Al-Quran Baitul Hasanah Jorong Pincuran, Tujuh Kanagarian Tanjung Bonai Aur Selatan" dimana didapat $r_{\text {hitung }}>r_{\text {tabel }}$, itu berarti hipotesis diterima.

Dari hasil pengujian hipotesis terlihat bahwa keharmonisan keluarga ada hubungannya dengan disiplin peserta di TPA baitul hasanah, berarti keharmonisan keluarga mempengaruhi disiplin peserta didik di TPABaitul Hasana. Anak yang tidak disiplin di TPA berasal dari keluarga yang tidak harmonis dimana perilaku anak tidak diarahkan dengan baik. Hail ini sesuai dengan pendapat Shochib (1997) keluarga sangat berperan penting dalam merapkan perilaku disiplin pada anak. Selanjudnya mengatakan Hawari (1997) keluarga memegang peran penting dalam pembentukan pribadi anak dan menentukan masa depannya. Salah satu faktor yang menyebabkan anak tidak disiplin adalah tidak berfungsinya orang tua sebagai teladan anak.Jadi peserta didik yang tidak disiplin berlatar belakang dari keluarga kurang harmonis, dimana didalam tidak terjadi komunikasi yang baik antar anggota keluarga dengan peserta didik seperti sikap orang tua yang tidak mengingatkan anak untuk pergi ke TPA tepat waktu sebelum jam pelajaran dimulai. Dan anak yang selalu melanggar peraturan yang ada di TPA berasal dari keluarga yang kurang harmonis dimana dalam keluarga orang tua selalu sibuk sehingga orang tua tidak mempunyai waktu untuk berkumpul dengan anggota keluargga untuk memecahkan masalah yang dihadapi anak yang mengakibatkan masalah masalah yang dihadapi anak di TPA tidak terselesaikan. Selanjudnya anak yang tidak disiplin 
juga berasal dari keluarga kacau dimana keluarga kacau selalu terjadi konflik, kekarasan orang tua dan serselisihan antar keluarga mengakibatkan peserta didik selalu menghadapi masalah di TPA seperti mengganggu teman, melawan kepada guru, dan tidak mau menjalankan sangsi yang telah diberikan karena seperta didik sudah terbiasa dengan keadaan seperti itu dirumah.

Dewantara (shochib 2010) disiplin sangat diperlukan anak agar memiliki budi pekerti yang baik, untuk itu perlunya keluarga yang kondusif untuk membentuk disiplin anak. Dalam upaya meningkatkan disiplin anak sebagai peserta didik di lingkungan keluarga maupun TPA, perlu dibentuknya lingkungan yang kondusif untuk menciptakan perilaku disiplin anak yang lebih baik. Lingkungan keluarga yang mempengaruhi proses pembentukan perilaku anak adalah menciptakan kehidupan berapa dalam keluarga. Keluarga yang tidak menciptakan kehidupan beragama yang baik akan menimbulkan perilaku negaritif oleh anak sebagai peserta didik di TPA, yang nantinya akan mempengaruhi disiplin anak dalam proses pembelajaran di TPA. Selanjudnya keluarga yang terlalu sibuk membuat anak merasa tidak diperhatikan sehingga masalah -masalah yang dihadapi anak tidak bisa terpecahkan. Komomukasi dalam keluarga juga akan berpengaruh terhadap kedisiplin anak di TPA, anak yang komunikasi keluargganya kurang baik akan mengakibatkan anak tidak mendapatkan arahan terhadap perilakunya, sehingga anak pertingkah sesuka hatinya.

Lifshitz (dalam hawari 2010) anak yang berasal dari keluarga kacau mengalami kesulitan dalam menerapkan disiplin pada dirinya baik dirumah maupun disekolah. Anak yang berasal dari keluarga yang tidak harmonis akan mengalami kesulitan untuk menerapkan disiplin disiplin di TPA, anak akan bertingkah sesuka hatinya di TPA dan anak tidak mempunyai tanggung jawab karena tidak ada kontrol dari orang tua. Keluarga yang tidak menerapkan nilai-nilai agama akan membuat keluarga tidak harmonis, dimana nilai-nilai agama adalah landasan untuk membentuk sikap dan perilaku seseorang. Meluangkan waktu 
dan berkumpul dengan keluarga sangat dibutuhkan untuk menunjang keluarga yang harmonis, jika terlalu orang tua selalu sibuk dengan pekerjaannya maka masalah yang dihadapi anak di TPA tidak bisa diselesaikan karena anak tidak mendapatkan arahan dari orang tua. Dalam keluarga yang komunikasi antara orang tua dan anak tidak berjalan dengan baik, seperti tidak mengingatkan anak pergi ke TPA, dan menasehati anak saar anak melakukan kesalahan maka anak akan tidak akan disiplin datang ke TPA, dan jika keluarga sering terjadi konflik maka anak di TPA akan mengalami masalah - malas seperti melawan kepada guru, menggu teman dan tidak melaksakan tanggung jawabnya karena peserta didik sudah terbiasa dengan kehidupan seperti itu dirumah. Untuk itu perlunya keharmonisan dalam keluarga untuk menjadikan anak yang memiliki disiplin di TPA. Hal ini senada dengan pendapat Reynold (dalam Shochib 2010) anak yang berhasil disekolah adalah anak yang berdasarkan dari keluarga penuh kasih sayang dan menerapkan disiplin berdasarkan kecintaan.

Dari pendapat di atas bahwa adanya hubungan antara persepsi keharmonisan keluarga dengan disiplin peserta didik, secara teoritis jika persepsi persepsi terhadap keharmonisan kurang baik maka disiplin peserta didik akan rendah, segitu juga sebaliknya jika persepsi terhadap keharmonisan keluarga baik atau positif makan disiplin anak di TPA akan tinggi.

\section{KESIMPULAN DAN SARAN}

\section{Kesimpulan}

Berdasarkan hasil penelitian yang telah diuraikan pada bab terdahulu dapat dikemukakan sebagai berikut: (1) keharmonisan keluarga peserta didik Taman Pendidikan Al-Quran Baitul Hasanah kurang harmonis, ini terlihat dari hasil penelitian bahwa banyaknya peserta didik menjawab instrument yang diberikan dengan jawaban jarang .Dalam penelitian ini keharmonisan keluarga dapat dilihat dari menciptakan kehipan beragama, mempunyai waktu bersama keluarga, komunikasi antar anggota kelaurga, saling menghargai antar sesama 
anggota keluarga, kuantitas dan kualitas konflik yang minim.dan hubungan atau ikatan yang erat antar anggota keluarga. (2) Displin peserta didik Taman Pendidikan Al-Quran Baitul Hasanah jorong pincuran Tujuh kanagarian Tanjung Bonai Aur Selatan juga rendah, berdasarkan hasil penelitian terlihat bahwa banyak responden menjawab intrumen yang diberikan dengan jawaban kurang setuju. Dalam penelitian ini, disiplin peserta didik dilihat dari ketepatan waktu, ketaatan dan tanggung jawab peserta didik di TPA baitul Hasanah. (3) Terdapat hubungan yang siknifikan antara keharmonisan keluarga dengan disiplin peserta didik di Taman Pendidikan Al-Quran Baitul Hasanah, Jorong Pincuran Tujuh, Kanagarian Tanjung Bonai Aur Selatan. Jadi dapat dikatakan apabila persepsi terhadap keharmonisan keluarga positif maka disiplin peserta didik di Taman Pendidikan Al-Quranpun tinggi, begitu juga sebaliknya apabila persepsi terhadap keharminisan keluarga negatif maka disiplin peserta didik di TPApun akan rendah.

\section{Saran}

Berdasarkan hasil penelitian, penelitian menyampaikan beberapa saran yaitu: (1) Berdasarkan hasil penelitian, disarankan kepada orang tua supaya dapat menciptakan hubungan yang harmonis dalam keluarga, misalnya dengan melakukan perbuatan sesuai dengan aturan agama yang baik, saling menghormati, saling memberi dukungan, perhatian dan kasih sayang dalam keluarga. Dengan demikian anak akan merasa aman, nyaman, dan bahagia dalam keluarganya dan anak akan berpersepsi keluarganya adalah keluarga yang harmonis. (2) Bagi pendidik di TPA, hendaknya meningkatkan disiplin peserta didik melalui pengawasan pelaksanaan tata tertib sekolah sehinga peserta didik dapat disiplin di TPA dan di luar TPA. (3) Kepada peserta didik disarankan untuk dapat meningkatkan disiplin di TPA agar memperoleh prestasi yang baik dengan berusaha menumbuhkan dan mengembangkan kemampuan dan potensi yang dimiliki, menyadari belajar sebagai kebutuhan diri untuk 
kehidupan sehari-hari. Selanjudnya peserta didik berusaha memcapai cita-cita yang diinginkan dengan melakukan kegiatan belajar sebaik mungkin.

\section{DAFTAR PUSTAKA}

Anora, Panji. 2001. Perilaku Organisasi.Jakarta; Balai Pustaka.

Hawari, D.1997. Al-Quran: Ilmu Kedokteran Jiwa dan Kesehatan Jiwa. Yokyakarta: Dana Bhakti Primayasa

Hurlock E. 1995. Psikologi Perkembangan (SuatuPendekatan Sepanjang Rentang Kehidupan). Jakarta: Erlangga

Nitisesmito, Alex. 1982. Menajemen Personalia. Jakarta: Clacia Indo

Poerwadarminta.2003. Kamus Besar Bahasa Indonesia. Jakarta: Balai Pustaka.

Shohib, Muhammad. 2010. Pola Asuh Orang Tua untuk Membentuk Anak Mengembangkan Disiplin Diri. Jakarta: Rineka Cipta. 